\title{
Modification of Conventional Drainage System Using Recharge Well
}

\author{
Sri Amini Yuni Astuti ${ }^{1, *}$ and Dinia Anggraheni ${ }^{2}$ \\ ${ }^{1}$ Civil Engineering Study Program, Faculty of Civil Engineering and Planning, Universitas Islam \\ Indonesia, Yogyakarta
}

\begin{abstract}
One of the popular recharge systems is a recharge well that directly receive rainwater from the roof of the house. In this study, recharge wells will be introduced and analyzed in a modification of conventional drainage. Area for this research was taken in Kimpulan Village, Sleman, Yogyakarta. Input discharge that enters the recharge well used free-flow formula through holes or pipes. The dimensions of recharge wells followed the Sunjoto's formula, but with $\mathrm{T}$ is the time of concentration, not the duration of the dominant rainfall. The result of this study showed that recharge well reduced the maximum discharge and dimensions of the channel. The reduction depends on the diameter of the connecting pipe, the height difference of the water level, depth of groundwater and permeability of the soil in the area. If a diameter pipe of $20 \mathrm{~cm}$ and a height difference of $1 \mathrm{~m}$ are used, it reduced the runoff discharge more than $17.3 \%$. For the study area, it was not feasible to build additional recharge wells, because it required a large number of wells, approximately 58 pieces, due to very small soil permeability of $3.5 .10^{-5}$ $\mathrm{m} / \mathrm{s}$.
\end{abstract}

\section{Introduction}

The population grows widely cause the need for infrastructure increase in an area, such as the addition of housing, offices, schools, sports buildings, and other buildings. Because of the increasing building, land use change occurred. An area used to be a catchment area, turn into an impermeable area. The changes in land use be an impermeable area, increase the runoff coefficient, which in turn increase the risk of flooding.

The occurrence of floods or puddles greatly disrupt the activities of residents in an area. It will be made a drainage system to overcome that condition. That is a system for removing excess water as quickly as possible, from a drainage channel to the natural river and ending up in the sea. It is known as conventional drainage systems.

Conventional drainage systems do not provide the opportunity for water to seep into the soil. Because of that conditions, there is a critical land which is flooding in the rainy season but drought in the dry season. To anticipate that problem, the drainage system should provide the opportunity that groundwater reserves are always available. But there is a new

\footnotetext{
* Corresponding author: amini yuni@uii.ac.id
} 
paradigm, commonly known as a sustainable drainage system. That is a drainage system using recharge systems such as recharge channels, recharge wells, catchment parks or reservoirs.

One recharge system that was popular is recharge well. That is a well that holds rainwater that falls on the roofs of buildings. The well is not designed as waterproof, then rainwater can enter the well and be absorbed into the soil.

Previous research was conducted by Indramaya and Purnama (2013). They carried out a study area in Dayu Baru Housing. The research had a goal to design recharge well in order to increase groundwater reserves (conservation). The method used a survey method. The measurement of the permeability used inverse auger hole method. The roof area was got by satellite imagery digitation. The dimensions of the recharge well were made by Sunjoto formula [1].

Astuti and Prasojo (2015) also did a research about recharge wells. They compared two methods to design the recharge well in a commercial building in Jalan Kaliurang Km 12, Yogyakarta. They used Sunjoto's and SNI 03-2453-2002 method. The research was done because collection and filling of groundwater are not balanced in Islamic University of Indonesia area. Then, to preserve the stability of the groundwater table, it should be designed to recharge wells. Infiltration rate was measured by ring-infiltrometer and used data for the last 10 years which was taken from 4 nearby stations. The dimension of recharge well was determined to be a circle of $1 \mathrm{~m}$ in diameter with a depth of well $2.5 \mathrm{~m}$. The result of the analysis showed that the number of wells of the SNI method is more (about 2 times to 4 times) compared to Sunjoto method. The bigger the infiltration rate, the roof area, and the repeat period, the number of recharge wells will be more. The recharge well has contributed greatly to the groundwater conservation effort, since it can accommodate the flow due to rainfall whit the return period of 5 years is more than $98 \%$ $[2]$.

Fatmawati and Sulistiono did a research about innovation of eco-drainage in Integrated Campus Universitas Islam Indonesia (UII) in 2017. The drainage system in the study area would be renew using the construction of recharge wells through the channel in Campus. The aim of that research is to know the effectivity of application of the eco-drainage by comparing the discharge that flowed out whether before and after using them. To calculate the mean rainfall area was used Isohyet Method, while to calculate the peak discharge was used Rational Method. The in-site test based on SNI-03-3986-1995 was used to find the soil permeability. The recharge wells were designed by the impermeable wall and flat permeable bottom construction. The result of the study shows that the runoff discharge decreased until $100 \%$ in the 2 years of the return period, $93,94 \%$ in the 5 years of the return period, and $81,52 \%$ in the 10 years of the return period [3].

Usually, as in the previous studies, input discharge is from the roof of a house, but in this research, a recharge well was created and connected to a conventional drainage channel.

The benefit of this paper is to provide a sustainable drainage system alternative, to solve the problem of inundation and flooding.

\section{Theoretical Basis}

\subsection{Drainage System}

The conventional drainage system is a system by which water is drained to an area out through channels and rivers to the sea. While the sustainable drainage system is a system by which water is drained to an outlet, other than through channels and rivers to the sea, also absorb into the soil. 


\subsection{Hydrologic Cycle}

The hydrologic cycle is the central focus of hydrology. The cycle has no beginning or end, and its many processes occur continuously. Water evaporates from the oceans and the land surface to become part of the atmosphere, water vapor is transported and lifted into the atmosphere until it condenses and precipitates on the land or the oceans, precipitated water may be intercepted by vegetation, become overland flow over the ground surface, infiltrate into the ground, flow through the soil as subsurface flow, and discharge into streams as surface runoff. Much of the intercepted water and surface runoff returns to the atmosphere through evaporation. The infiltrated water may percolate deeper to recharge groundwater, later emerging in springs or seeping into streams to form surface runoff, and finally flowing out to the sea or evaporating into the atmosphere as the hydrologic cycle continues (Chow, et al., 1988) [4].

\subsection{Frequency Analysis}

Frequency analysis is a way of determining the rainfall or discharge design of a watershed based on rainfall or discharge data of previous years. The rainfall or discharge data follows one of the known distributions, namely: Normal Distribution, Normal Log Distribution, Gumbel, Pearson and Log Pearson type III.

To determine the type of distribution, the statistical parameters were calculated, namely: mean, standard deviation, the coefficient of variation, kurtosis coefficient and skewness coefficient (Triatmodjo, 2008) [5].

Rainfall or discharge design is calculated by the following formula:

$$
X_{T}=\bar{X}+K_{T} . S
$$

Where $X_{T}$ is the design-rainfall or discharge with the return period $\mathrm{T}, \bar{X}$ is mean of rainfall or discharge data, $K_{T}$ is the frequency coefficient of the return period $\mathrm{T}$, and $S$ is the standard deviation.

\subsection{Rational Method}

The rational method is one of the methods to generate a design-discharge when there is no discharge measurement data but there are rainfall data and area of the watershed is no more than $3 \mathrm{~km}^{2}$. The formula used was as follows:

$$
Q_{T}=0.002778 . C . I_{T} . A
$$

Where $Q_{T}$ is the design-discharge with the return period T, $C$ is the runoff coefficient, $I_{T}$ is the intensity of design-rainfall wit the return period $\mathrm{T}$ ( $\mathrm{mm} /$ hour), and $A$ is an area of the watershed (ha).

The intensity of design-rainfall was calculated by Mononobe Formula as follow:

$$
I_{T}=\left(\frac{R_{T}}{24}\right) \cdot\left(\frac{24}{t_{C}}\right)^{2 / 3}
$$

Where $R_{T}$ is the design-rainfall with the return period $\mathrm{T}(\mathrm{mm})$ and $t c$ is the time of concentration (hour). 


\subsection{Recharge Well}

The recharge well is a hole to put water into the soil, while a well of drinking water serves to take groundwater to the surface. Thus construction and depth are different. The recharge well is dug with depths above the groundwater level, while the wells of drinking water are dug deeper or below the water table.

The working principle of recharge well is to channel and collect rainwater that falls on the roof into holes or wells so that water can gradually seep into the soil. Thus, more water enters the soil and fewer flows as runoff.

Sunjoto in 1988 proposed a formula as the basis for calculating the depth of recharge well, as follows:

$$
H=\frac{Q}{F K}\left(1-e^{\frac{-F K T}{\pi \cdot r^{2}}}\right)
$$

Where $H$ is the depth of recharge well (m), $Q$ is the input discharge of rainwater that falls on the roof $\left(\mathrm{m}^{3} / \mathrm{s}\right), Q$ is calculated by Formula (2), but $A$ is not as an area of the watershed but the roof. $F$ is the geometric factor of the well, $K$ is the soil permeability $(\mathrm{m} / \mathrm{s}), T$ is the time of the dominant rainfall (s), and $r$ is the radius of the well (m) [6].

\subsection{Modification of Drainage System by Recharge Well}

The design of recharge wells added to a conventional drainage system, following the formula expressed in Equation (5).

$$
Q=0,25 \cdot \pi \cdot d^{2} \cdot \sqrt{2 \cdot g \cdot \Delta h}
$$

Where $Q$ is input discharge which enters into recharge well from the conventional drainage channel through the connecting pipe $\left(\mathrm{m}^{3} / \mathrm{s}\right), d$ is the diameter of the connecting pipe $(\mathrm{m}), g$ is the gravity acceleration $\left(\mathrm{m} / \mathrm{s}^{2}\right)$, and $\Delta h$ is the difference of water level in the channel and elevation of the tip of the connecting pipe (m). As shown clearly in Fig.1, how input discharge was calculated.

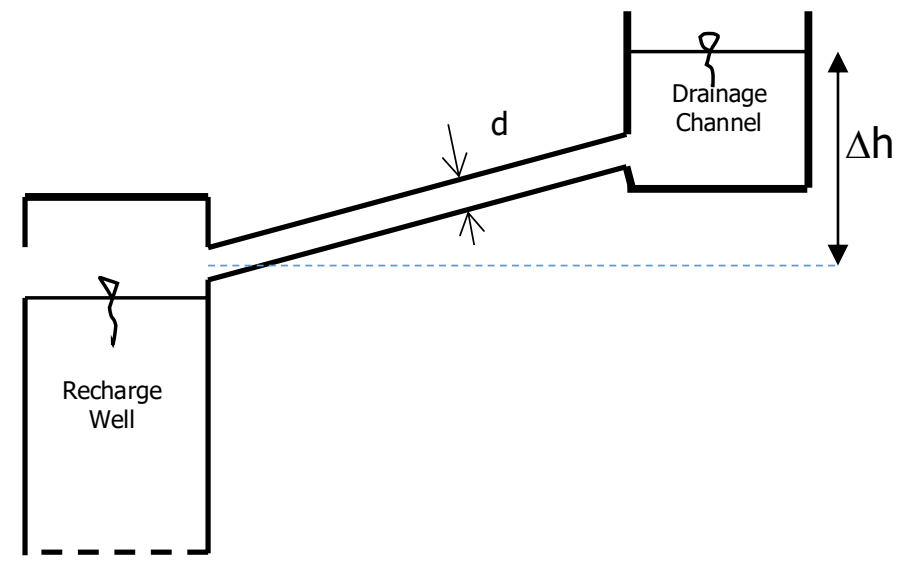

Fig. 1. Modification of Conventional Drainage Channel and Recharge Well 


\section{Methodology}

The study area was in Kimpulan Hamlet, Umbulmartani Village, Ngaglik District, Sleman, Yogyakarta. An area of the watershed is 3.22 ha. The channel length is $188.9 \mathrm{~m}$, with a slope of 0.0193 and a concentration time of 0.19 hours. The rainfall data was taken from the nearest station of Prumpung Station for 10 years, from 2006 to 2015. The runoff coefficient based on land use conditions in May 2018. The length and slope of the channel were taken from the previous field survey (Rizqiawati, 2018) [7]. The location of this research is shown in Fig. 2.

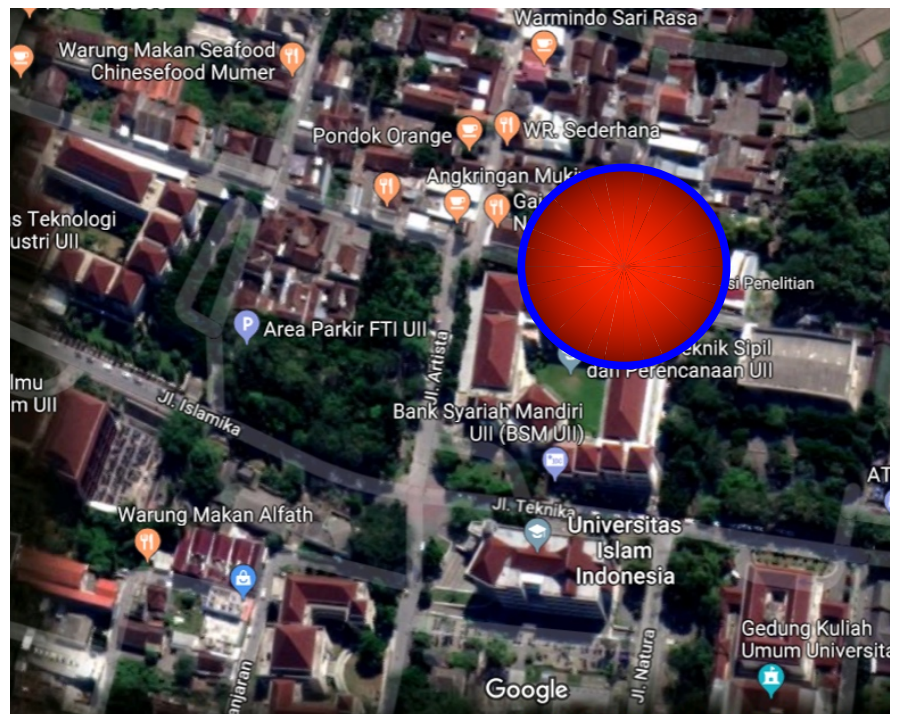

Fig. 2. The Location of Research Study Area

The return period of design-rainfalls was used the 2, 5, and 10 years. Then, the dimension of the conventional discharge channel was calculated. Furthermore, a recharge well is designed to be added to the drainage system. After that, the input discharge which entering the recharge well was calculated. Then, the reduction of runoff through the drainage channel can be calculated and redesigned the dimension after using additional the recharge well.

\section{Data Analysis}

\subsection{Conventional Drainage Channel Planning}

Rizqiawati (2008) calculated the design-rainfalls in the return period of 2, 5, and 10 years is shown in Table 1.

Table 1. The Design-Rainfall Using Log Pearson III Method

\begin{tabular}{|c|c|c|c|c|c|}
\hline T (year) & Log $\mathbf{Y}_{\mathbf{r t}}$ & $\boldsymbol{S}_{\boldsymbol{y}}$ & $\boldsymbol{K}_{\boldsymbol{T}}$ & $\boldsymbol{Y}_{\boldsymbol{T}}$ & $\mathbf{R}_{\mathbf{T}}(\mathbf{m m})$ \\
\hline 2 & 1.9434 & 0.1585 & -0.0234 & 1.9397 & 87.0288 \\
\hline 5 & 1.9434 & 0.1585 & 0.8336 & 2.0755 & 118.9950 \\
\hline 10 & 1.9434 & 0.1585 & 1.2956 & 2.1488 & 140.8550 \\
\hline
\end{tabular}


The next, the design-discharge in the return period of 2, 5, and 10 years was calculated by Eq. (2) and (3), shown in Table 2.

Table 2. The Design-Discharge with The Return Period (T)

\begin{tabular}{|c|c|c|c|c|c|}
\hline T (year) & $\mathbf{R}_{\mathbf{T}}(\mathbf{m m})$ & $\boldsymbol{C}$ & $\boldsymbol{t}_{\boldsymbol{c}}$ (hour) & $\boldsymbol{I}_{\boldsymbol{T}}(\mathbf{m m} / \mathbf{j a m})$ & $\boldsymbol{Q}_{\boldsymbol{T}}\left(\mathbf{m}^{\mathbf{3}} / \mathbf{s}\right)$ \\
\hline 2 & 87.0288 & 0.6074 & 0.19 & 91.46 & 0.4969 \\
\hline 5 & 118.995 & 0.6074 & 0.19 & 124.82 & 0.6782 \\
\hline 10 & 140.855 & 0.6074 & 0.19 & 147.75 & 0.8028 \\
\hline
\end{tabular}

Then, the dimension of the conventional drainage channel was calculated using Manning Formula, with the Manning Coefficient of concrete $(n)$ is 0,012 , the slope is 0.0193 , and the economic dimension, $b=2 h$, shown in Table 3 . Where $b$ is the width and $h$ is the height of the channel.

Table 3. The Dimension of The Conventional Drainage Channel without Modification

\begin{tabular}{|c|c|c|c|c|}
\hline $\boldsymbol{Q}_{T}\left(\mathbf{m}^{\mathbf{3}} / \mathbf{s}\right)$ & $\boldsymbol{n}$ & $\boldsymbol{S}_{\boldsymbol{0}}$ & $\boldsymbol{h}(\mathbf{m})$ & $\boldsymbol{b}(\mathbf{m})$ \\
\hline 0.4969 & 0.012 & 0.0193 & $0.2816 \approx 0.30$ & 0.60 \\
\hline 0.6782 & 0.012 & 0.0193 & $0.3164 \approx 0.32$ & 0.64 \\
\hline 0.8028 & 0.012 & 0.0193 & $0.3371 \approx 0.34$ & 0.68 \\
\hline
\end{tabular}

\subsection{Modification Planning of Conventional Drainage Channel Using Recharge Well}

Modification of a conventional drainage system is to add recharge well to the conventional drainage channel. Because of added the recharge well, there was a reduction of runoff discharge. The reduction depends on the number of recharge wells, well height, well geometry shape, soil permeability coefficient, the height difference between the water level in the channel and the tip of pipe, and also the diameter of connecting pipe.

If the recharge well was used with a diameter of $1 \mathrm{~m}$, the geometrical well form $\mathrm{F}=5.5$ $\mathrm{r}$, the well height of $2 \mathrm{~m}$ and the soil condition in the area has a permeability of land of $3.5 .10-5 \mathrm{~m} / \mathrm{s}$. So the reduction of runoff in the channel can be seen in Table 4 . There are 4 difference of Discharge of Channel (Q);

Table 4. Percentage of Runoff Discharge Reduction after Modification of Addition of Recharge Well

\begin{tabular}{|c|c|c|c|c|c|c|}
\hline $\begin{array}{c}\text { Discharge } \\
\text { in } \\
\text { Channel } \\
\left(Q_{T}\right) \\
\left(\mathbf{m}^{3} / \mathbf{s}\right)\end{array}$ & $\begin{array}{c}\text { Permeability } \\
\text { Coefficient } \\
(\mathrm{K}) \\
(\mathrm{m} / \mathrm{s})\end{array}$ & $\begin{array}{c}\text { Difference } \\
\text { of } \\
\text { Elevation } \\
(\Delta h) \\
(\mathbf{m})\end{array}$ & $\begin{array}{c}\text { The } \\
\text { Diameter of } \\
\text { Connecting } \\
\text { Pipe } \\
\text { (m) } \\
\end{array}$ & $\begin{array}{l}\text { Q inflow } \\
\text { of the } \\
\text { Recharge } \\
\text { Well } \\
\left(\mathbf{m}^{3} / \mathbf{s}\right)\end{array}$ & $\begin{array}{l}\text { Number } \\
\text { of Wells }\end{array}$ & $\begin{array}{l}\text { Percentage } \\
\text { of The } \\
\text { Discharge } \\
\text { Reduction } \\
(\%)\end{array}$ \\
\hline \multirow{3}{*}{0,4969} & \multirow{3}{*}{$3,5 \cdot 10^{-4}$} & 0,5 & 0,2 & 0,0984 & 29 & $19,8 \%$ \\
\hline & & 1 & 0,2 & 0,1392 & 41 & $28 \%$ \\
\hline & & 1 & 0,3 & 0,3131 & 92 & $63 \%$ \\
\hline \multirow{3}{*}{0,4969} & \multirow{3}{*}{$3,5.10^{-5}$} & 0,5 & 0,2 & 0,0984 & 41 & $19,8 \%$ \\
\hline & & 1 & 0,2 & 0,1392 & 58 & $28 \%$ \\
\hline & & 1 & 0,3 & 0,3131 & 130 & $63 \%$ \\
\hline \multirow{3}{*}{0,6782} & \multirow{3}{*}{$3,5.10^{-4}$} & 0,5 & 0,2 & 0,0984 & 29 & $14,5 \%$ \\
\hline & & 1 & 0,2 & 0,1392 & 41 & $20,5 \%$ \\
\hline & & 1 & 0,3 & 0,3131 & 92 & $46,2 \%$ \\
\hline
\end{tabular}




\begin{tabular}{|c|c|c|c|c|c|c|}
\hline $\begin{array}{c}\text { Discharge } \\
\text { in } \\
\text { Channel } \\
\left(Q_{T}\right) \\
\left(\mathbf{m}^{3} / \mathbf{s}\right)\end{array}$ & $\begin{array}{c}\text { Permeability } \\
\text { Coefficient } \\
(\mathbf{K}) \\
(\mathbf{m} / \mathbf{s})\end{array}$ & $\begin{array}{c}\text { Difference } \\
\text { of } \\
\text { Elevation } \\
(\Delta h) \\
(\mathbf{m})\end{array}$ & $\begin{array}{c}\text { The } \\
\text { Diameter of } \\
\text { Connecting } \\
\text { Pipe } \\
\text { (m) }\end{array}$ & $\begin{array}{l}\text { Q inflow } \\
\text { of the } \\
\text { Recharge } \\
\text { Well } \\
\left(\mathbf{m}^{3} / \mathbf{s}\right)\end{array}$ & $\begin{array}{l}\text { Number } \\
\text { of Wells }\end{array}$ & $\begin{array}{l}\text { Percentage } \\
\text { of The } \\
\text { Discharge } \\
\text { Reduction } \\
(\%)\end{array}$ \\
\hline \multirow{3}{*}{0,6782} & \multirow{3}{*}{$3,5 \cdot 10^{-5}$} & 0,5 & 0,2 & 0,0984 & 41 & $14,5 \%$ \\
\hline & & 1 & 0,2 & 0,1392 & 58 & $20,5 \%$ \\
\hline & & 1 & 0,3 & 0,3131 & 130 & $46,2 \%$ \\
\hline \multirow{3}{*}{0,8028} & \multirow{3}{*}{$3,5.10^{-4}$} & 0,5 & 0,2 & 0,0984 & 29 & $12,3 \%$ \\
\hline & & 1 & 0,2 & 0,1392 & 41 & $17,3 \%$ \\
\hline & & 1 & 0,3 & 0,3131 & 92 & $39 \%$ \\
\hline \multirow{3}{*}{0,8028} & \multirow{3}{*}{$3,5.10^{-5}$} & 0,5 & 0,2 & 0,0984 & 41 & $12,3 \%$ \\
\hline & & 1 & 0,2 & 0,1392 & 58 & $17,3 \%$ \\
\hline & & 1 & 0,3 & 0,3131 & 130 & $39 \%$ \\
\hline
\end{tabular}

The reduction of runoff discharge in the channel caused the dimension of the channel can be reduced. The dimensions of the channels after modification using the addition of the recharge wells are as shown in Table 5 below.

Table 5. The Dimensions of The Conventional Drainage Channel Using Recharge Wells

\begin{tabular}{|c|c|c|c|c|}
\hline $\begin{array}{c}Q_{T} \\
\left(\mathrm{~m}^{3} / \mathrm{s}\right)\end{array}$ & $\begin{array}{c}Q \text { reduction } \\
\left(\mathrm{m}^{3} / \mathrm{s}\right)\end{array}$ & $S_{0}$ & $\begin{array}{c}h \\
(\mathrm{~m})\end{array}$ & $\begin{array}{c}b \\
(\mathrm{~m})\end{array}$ \\
\hline 0.4969 & 0.3577 & 0.0193 & $0.2489 \approx 0.25$ & 0.50 \\
\hline 0.6782 & 0.5390 & 0.0193 & $0.2903 \approx 0.30$ & 0.60 \\
\hline 0.8028 & 0.6636 & 0.0193 & $0.3139 \approx 0.32$ & 0.64 \\
\hline
\end{tabular}

\section{Result and Discussion}

The percentage of the recharge reduction was affected by the diameter of the connecting pipe, the height difference between the water level in the channel and the elevation of the tip of pipe, the design-discharge with the return period $(\mathrm{T})$. The higher the height difference, the greater the input discharge of the recharge well. Meanwhile, the height difference cannot be planned arbitrarily but has to adapt to field conditions, especially the groundwater level in the place.

Soil permeability is crucial, whether the addition of recharge wells is feasible or not because soil permeability determines the number of recharge wells needed. Can be seen in Table 4, if the permeability is large enough, the recharge wells needed are few numbers (for the same percentage of discharge reduction). So it is feasible to make modifications with the addition of recharge wells. However, in the study area, the soil permeability is small enough, which the number $(\mathrm{K})$ is $3.5 \cdot 10^{-5} \mathrm{~m} / \mathrm{s}$. It required a large number of recharge wells, which is not feasible to build.

The input discharge of the recharge well follows Eq. 5 above instead of following Eq. 4 (with the dimensions of the recharge well). The Eq. 5 was used to calculate the input discharge because it is more appropriate. The input discharge of the recharge well depends on the height difference of water level in the channel and the elevation of the tip of the connecting pipe, based on Eq. 5 . 


\section{Conclusion}

From the result and discussion, it can be concluded that:

a. modification of the drainage system with the addition of recharge wells can reduce the maximum discharge of the channel, in other words, there is a reduction in the dimensions of the required channel,

b. the reduction of runoff discharge depends on the diameter of the connecting pipe, the design-height difference, the depth of the groundwater level and the permeability of the soil in the area. If a $20 \mathrm{~cm}$ diameter pipe is used and a height difference of $1 \mathrm{~m}$, there was a discharge reduction of more than $17.3 \%$,

c. The feasibility of adding recharge wells mainly depends on the permeability of the land in the area. In the study area, the soil permeability $(\mathrm{K}) 3.5 .10^{-5} \mathrm{~m} / \mathrm{s}$ which is the very small number. It was not feasible to add the recharge wells, because it needs a lot of wells, and

d. the design-input discharge that entered the recharge well on the conventional drainage modification did not follow the regular formula but followed the free flow formula through holes or pipes. The dimension of the recharge well followed the Sunjoto's Formula, with the parameter $\mathrm{T}$ being the time of concentration, not the dominant duration of rain.

\section{Recommendations}

For the better next research, it should be recommended that:

a. the input discharge which entering the absorption well, should be observed directly with the physical model, to find out how far the validity of the calculation with the free flow formula through holes or pipes,

b. In an area which has very small soil permeability, a vertical cavity hole whose soil is replaced by greater permeability. So that water can seep faster, reach groundwater level, and follow groundwater flow.

\section{References}

1. Indramaya, E. A. \& Purnama, I. L. S., Rancangan Sumur Resapan Air Hujan sebagai Salah Satu Usaha Konservasi Air Tanah di Perumahan Dayu Baru Kabupaten Sleman Daerah Istimewa Yogyakarta. Jurnal Bumi Indonesia, 15 November, 2(3), pp. 47-54, (2013)

2. Astuti, S. A. A. \& Prasojo, R. A., Perbandingan Perancangan Sumur Resapan Air Hujan Menggunakan Metode Sunjoto dan SNI 03-2453-2002 pada Bangunan Komersial di Jalan Kaliurang Km. 12 Sleman Yogyakarta. Teknisia, 2 November, XX(2), pp. 142153, (2005)

3. Fatmawati, K. \& Sulistiono, B., Efektivitas Penerapan Eko-Drainase dengan Sumur Resapan Kampus Terpadu UII. Prosiding Kolokium KPSTS FTSP UII, Agustus, Volume XI, pp. 275-286, (2017)

4. Chow, V. T., Maidment, D. R. \& Mays, L. W., Applied Hydrology. International Edition penyunt.

5. Singapore: McGraw-Hill, (1988)

6. Triatmodjo, B., Hidrologi Terapan. Yogyakarta: Beta Offset, (2008) 
7. Sunjoto, Teknik Drainase Pro-Air sebagai Konservasi Pemukiman. Yogyakarta: Jurusan Teknik Sipil dan Lingkungan Fakultas Teknik Universitas Gadjah Mada, (2015).

8. Rizqiawati, N. U., Evaluasi Kapasitas Saluran Drainase (Studi Kasus: Dusun Kimpulan, Desa Umbul Martani). Tugas Akhir penyunt. Yogyakarta: Universitas Islam Indonesia, (2018). 